\title{
Post-liberation Politics and Political Space in Eritrea: Interrogating Aspirations among Educated Youth
}

DOI:

10.1080/00220388.2017.1311409

\section{Document Version}

Accepted author manuscript

Link to publication record in Manchester Research Explorer

\section{Citation for published version (APA):}

Müller, T. R. (2018). Post-liberation Politics and Political Space in Eritrea: Interrogating Aspirations among Educated Youth. Journal of Development Studies, 54(6), 968-982.

https://doi.org/10.1080/00220388.2017.1311409

\section{Published in:}

Journal of Development Studies

\section{Citing this paper}

Please note that where the full-text provided on Manchester Research Explorer is the Author Accepted Manuscript or Proof version this may differ from the final Published version. If citing, it is advised that you check and use the publisher's definitive version.

\section{General rights}

Copyright and moral rights for the publications made accessible in the Research Explorer are retained by the authors and/or other copyright owners and it is a condition of accessing publications that users recognise and abide by the legal requirements associated with these rights.

\section{Takedown policy}

If you believe that this document breaches copyright please refer to the University of Manchester's Takedown Procedures [http://man.ac.uk/04Y6Bo] or contact uml.scholarlycommunications@manchester.ac.uk providing relevant details, so we can investigate your claim.

\section{OPEN ACCESS}


Journal of Development Studies, accepted manuscript version, 16/03/2017

\title{
Post-liberation Politics and Political Space in Eritrea - Interrogating Aspirations among Educated Youth
}

Tanja R. Müller, Global Development Institute, University of Manchester

\begin{abstract}
This article discusses post-liberation politics in Eritrea through the lens of political space, making use of empirical data collected between 1996 and 2006 among youth in higher education. Political space is defined as a relational space whose boundaries are being created in constant balancing acts between enforced citizenship obligations and personal aspirations. This definition allows for an analysis of the contradiction between national development objectives and personal aspirations in the lives of research-protagonists, and through this provides important insights into the nature of the Eritrean state. Main findings demonstrate how closures of political space ultimately undermine important state objectives.
\end{abstract}

\section{KEYWORDS}

Political space - capacity to aspire - Eritrea - youth - post-liberation politics - higher education - aspirations

\section{Introduction}

Post liberation states, consolidated after 'revolutionary' wars or armed insurgencies, are often characterised by similar political dynamics (Dorman, 2006). Among those is a drive by post-revolutionary leaders to legitimise state ownership through the mobilisation of new constituencies into the wider revolutionary project, and in that 
process tight control of political space (see for example Burgess, 2005; Kriger, 2009; Valentin, 2007; Xu, 2011 on Zanzibar, Zimbabwe, Vietnam and China respectively). This makes political space a useful lens through which to interrogate the nature of such states. Political space is defined here as an arena created in balancing acts between state-enforced citizenship obligations and contrasting personal aspirations of citizens. This definition is put forward because youth are a vital constituency in institutionalising revolutionary value systems in state politics, and an important means to mould youth into progressive post-liberation leaders is the opening of new educational opportunities. Youth who benefit from those are however expected to forgo personal aspirations if these are not in line with 'revolutionary values' as defined by respective governments (see for example Bayly, 2004; Müller, 2007; 2014; Panzer, 2009). Such an approach ignores the fact that educational opportunities are strongly related to future aspirations, part of the wider 'capacity to aspire' (Appadurai, 2004), that while being embedded into hegemonic norms and belief systems has a strong personalized component. A seemingly progressive political agenda that offers youth new educational opportunities only to curtail those subsequently through tight control mechanisms and the closure of aspirational space is thus bound to result in an increasing gulf between post-liberation leaders and youth. This has important repercussions for any post-liberation project more generally.

This paper looks at these processes in relation to Eritrea as a contemporary postliberation state, and does so through a concrete focus on the lived experiences of youth in higher education. It analyses their life trajectories as embedded within the political reality of an overbearing state, and shows in detail how the closure of political space as aspirational space has prevented youth from using their education 
and expertise for national development. This in turn undermines important state objectives.

\section{Political space as relational space: complexities of state-citizen relations}

Political space in much of the literature has been discussed as exclusionary, as a zero sum concept where one actor (usually the state) gains or looses at the expense of other actors (see for example Bratton, 1989). In this conceptualisation, an opening of political space occurs when actors beyond the state gain the ability to oppose or critique the political leadership (van de Walle, 2005). In a similar vein, Carothers (2002) defines political space as political contestation by opposition actors or civil society at large, and thus indirectly as an arena created by the state.

In my usage of political space I move away from this implicit understanding of political space as the product of resistance by non-state-actors. Instead, I follow Harvey's understanding of political space as relational space, as an arena jointly created by state action and its interpretation by those acted upon, the citizenry at large (Harvey, 2006). An understanding of political space as fluid implies that the ways in which individual citizens, population groups or organizations perceive political space and internalize its boundaries not only interact with state policies but also shape civil (or political) action that contest those.

Such an understanding makes it impossible to 'measure' the amount of political space in any geographical setting at any given moment in time (see also Beswick, 2010), but calls for a focus on the actual encounters that create or supress political space. Boudreau (2007) for example demonstrates how a dynamic understanding of political space, based on interactions between the state and society actors, can reshape the state, using the example of Toronto in Canada. In contrast, Beswick (2010) in her analysis 
of political space in post-genocide Rwanda discusses how its internalized boundaries result in the enforcement of state dominance.

In post-liberation states like Rwanda and Eritrea, internalized conceptions of political space are often strongly related to wider narratives of nationalism and definitions of citizenship, and the ways in which those are enforced by a centralised state that is imagined as extremely powerful. A number of recent articles have interrogated the complexities of state-citizen relations in Eritrea. This work has brought to the fore the tensions between top-down and bottom-up understandings of citizenship obligations within a highly centralized state that seeks hegemonic control not only within the country but equally over its substantial diaspora (see for example Bozzini, 2015; Hirt, 2015; Opas and McMurray, 2015; Woldemikael, 2013). One important focus has centred on contestations by and within the Eritrean diaspora. Important themes here include cyberspace as a key arena in the reconfiguration of nationalism (Bernal, 2006; 2013a; 2013b) and religion as a space to create 'subversive' understandings of Eritrean identity and notions of citizenship (Hepner, 2003; Sabar and Rotbard, 2015). A second strand of work has focused on urban youth in the Eritrean capital Asmara and strategies of evasion (Treiber, 2009). Eritrea has also been described as a particular kind of gatekeeper state, where nationalism is being sustained by the flight of its citizens, who use 'exit' as a way to escape and fulfil their perceived obligations as citizens (Poole, 2013; for dynamcis of exit and voice see Müller, 2012a); as well as enacting a policy of graduated citizenship (Hepner and Tecle, 2013; Riggan, 2013). What unites these writings is an analysis of how everyday life has been quasipoliticized through various mechanisms of government enforcement and control. These mechanisms are most visible in national service obligations within Eritrea and the two percent diaspora tax for those outside its physical borders (see Kibreab, 2009 
for the former and Tecle and Goldring, 2013, for the latter), but in fact make every act of interpreting government mandates in one's own way an act of changing the boundaries of political space.

Those dynamcis become particularly prominent in the sphere of (higher) education, not least because educational institutions are geared towards self-improvement and through this self-improvement ultimately national development, but at the same time act as important means to achieve personalized aspirations (Müller, 2005; Riggan, 2016). Riggan has explored this in detail focusing on secondary school teachers as middle actors who enforce and evade government dictates, and in doing so 'recalibrate their relationship with the state' (Riggan, 2016: 206), creating, I would argue, reshaped political spaces.

My entry point offers an additional dimension, in focusing more directly on the cohort of those educated for future leadership roles within the national project, in concrete those in higher education. While only a relatively small number of Eritreans gain access to any form of higher education - and conditions of everyday life are indeed quite different for many of those who do not succeed in doing so (see Müller, 2012b) - among those in higher education, the balancing act between (enforced) citizenship obligations and the realization of personal aspirations becomes particularly pronounced. Not only do such aspirations easily become forms of betrayal in the eyes of those who claim state-ownership, namely key functionaries of the ruling party, key government personnel and military commanders, who all aim to strictly enforce national duty and service to the state. The realisation of personal aspirations in this scenario becomes almost an act of political defiance, even if not necessarily intended as such by those who carry it out. It thus challenges the boundaries of political space 
as an arena jointly created by government dictates and citizens' responses, in this case those of youth in higher education.

I will investigate these dynamics focusing predominately on the lives of former students at the University of Asmara (UoA) and their struggles to put personal aspirations into practice, while often trying to maintain some form of loyalty to the wider post-liberation project. In doing so through a conceptualisation of political space as aspirational space, whose boundaries are being created in constant balancing acts between personal aspirations and enforced citizenship obligations, I engage with the key question raised by Harvey $(2006: 277)$ in relation to political space: How does the relational world of experience - in this case the experience of a (perceived) allpowerful post-liberation state - get internalized within political subjects to support different lines of thinking and action.

This focus on concrete life trajectories in order to illuminate political space as aspirational, spanning a timeframe of 20 years including recent data from within the country, provides temporal and historical depth as well as, I argue, unique insights into wider processes of post-liberation politics in Eritrea.

\section{Methodology}

Methodologically, the paper draws on interview, observation and survey data collected between 1996 and 2016. I have conducted research in Eritrea each year between 1996 and 2006, and spent the whole academic year 2000/2001 at the UoA. I subsequently returned to Eritrea in 2011, 2015 and 2016.

A core focus of my research in Eritrea centres on life history interviews with key protagonists. This paper takes as its point of departure a subsection of interviews among women students at the UoA, collected for a wider study on elite women. For 
the original study, 29 women were purposefully selected and interviewed in multiple sessions in 2000/2001. One theme was future aspirations and how those were connected with wider political developments at the time, a period that partly overlapped with the fighting phase of the 1998-2000 war with Ethiopia (for details on this war see Tekeste and Tronvoll, 2000). In addition, I conducted a survey on these themes among a wider group of students of both sexes based on stratified sampling methods. ${ }^{1}$ Survey findings were in line with findings from the interview data, suggesting no substantial differences between the sexes.

In subsequent years I maintained contact with the original 29 women where feasible, and with seven women I am still in conversation. From 1996 onwards, I have conducted key informant interviews with staff in various ministries, at the UoA, and with other stakeholders. A number of these key informants still occupy positions similar to those when I first encountered them and I have re-engaged with many of them during subsequent visits, most recently in July 2016. During visits in 2006 and 2011, I also conducted informal interviews with students at the College of Mai Nefhi, one of the colleges that replaced the UoA from 2004 onwards. In 2015 I conducted such interviews with students of pharmacy at the College of Health Sciences in Asmara and Masters students in other subjects. Students who participated in these interviews were recruited informally during visits to their respective institutions and agreed to share their experiences with me.

Taken together, while not generalizable in a broad sense, the life history data presented here, combined with insights from key informants and observations, provides a unique vantage point from which to analyse political space as aspirational space in Eritrea. It also adds an important empirical dimension to the contemporary literature on Eritrea, as it includes data from recent in-country visits. And while, as 
Reid as aptly argued, 'being there' in itself might not always add analytical value, it allows a more balanced understanding and 'facilitates the entry of Eritrean voices' from within (instead of predominately from the outside) into the analysis (Reid, 2009: 210).

In the remainder of this article I will thus interrogate the changing dynamics of postliberation politics and political space in Eritrea partly through the lens of three concrete life trajectories of women formerly at the UoA, supplemented by other empirical data. Those three individual histories have been chosen because they provide an exemplary in-depths understanding of the major dynamics at work in relation to internalising boundaries of political space as aspirational in the arena of higher education. All three initially benefitted from a progressive political agenda that subsequently proved too rigid to trust the promises it once made, forcing not only research protagonists into impossible trade-offs but also curtailing a meaningful higher education sector.

In order to put these personal trajectories into context, the subsequent sections will firstly discuss changing patterns of political space within Eritrea, largely focusing on the area of higher education, before presenting and analysing these life trajectories. The paper will then engage with more recent dynamics in relation to youth in higher education and the balancing act of realizing aspirations versus state obligations.

\section{Background: Changing Patterns of Political space within Eritrea}

Eritrea as an independent state de-facto emerged in 1991, after one of Africa's longest liberation wars. The early 1990 s were characterized by the hubris of the end-of history narrative and the transition paradigm that saw a global move from various forms of undemocratic rule towards 'Western' style democracy (Carothers, 2002; 
Fukuyama, 1992).

The governance philosophy and governing practices of the Eritrean political leadership, in contrast, were based on Leninist concepts of top-down decision making combined with political indoctrination and mobilization (Connell, 2005; Pool, 2001). Those principles had been put into practice in the quasi-state the liberation movement governed in early-liberated areas of Eritrea under conditions of war. The fact that military success had indeed brought Eritrean independence, coupled with the euphoria that accompanied the 'third wave' of democracy (Huntington, 1991), gave the postliberation government legitimacy not only internally but equally internationally (Tronvoll and Mekonnen, 2014). That the former liberation movement, the Eritrean People's Liberation Front (EPLF), morphed into a mass party, the People's Front for Democracy and Justice (PFDJ), had in fact captured the state was ignored by key actors in the international community. Thus Eritrea, while in practice governed according to similar principles of control and coercion as the former quasi-state, was, together with Ethiopia, Uganda and Rwanda, praised as a model for post-conflict governance in Africa (Ottaway, 1999).

Progressive politics in the eyes of foreign governments, the donor community and international financial institutions were underpinned by the government's zeal to develop the country economically. Indeed, substantive gains were made in the immediate years after political independence in terms of economic development and the provision of social goods, in particular in relation to rural development, health and education (Hirt, 2000).

The latter is of particular relevance when looking at progressive politics. Educated youth are often the core group to engage in political action potentially challenging the status quo. In line with this, secondary schools and universities are important sites for 
the analysis of political space. In fact, core members of the political elite of the EPLF/PFDJ became politically active as students either in secondary schools in Eritrea or at Addis Ababa university. From the latter many joined the liberation movements during the mid-1970s, and more generally Eritrean students within Eritrea and at universities in the wider region were a vital force in keeping the spirit of independence alive (Ammar, 1997).

Consequently, the expansion of secondary education and the re-opening of the UoA, the latter closed and partly dismantled by Ethiopian authorities in 1990, was a key priority of the new Eritrean government - albeit with the narrow objective to mobilize new population groups into becoming skilled contributors to the PFDJ state-building project. For the UoA this produced a two-fold dynamic: On the one hand it was regarded as suspect by the ruling elite as an institution that would hinder transferring the values of sacrifice of the liberation struggle. On the other hand graduates in subjects with clear benefits for the modernization of Eritrea were regarded as vital for future national development (Müller, 2004; Reid, 2005).

Upon completion of their degree and during the summer break, students were to complete national service in pre-determined institutions. University students were thus bound by a framework in which the common purpose of higher education, the fulfilment of (personal) career ambitions, was expected to be absent. In contrast, education was treated as an instrument to enforce 'the close relationship between the people and the leadership' (interview, male, former EPLF fighter, then ministry official, Asmara, Eritrea, 20 March 2001). This in turn implied that treating one's university education as a route towards personal fulfilment was interpreted as a form of 'betrayal'.

In the years after independence, a majority of students internalized parts of the 
obligation to treat their university education as a means to 'serve the nation', thus acknowledging the curtailment of aspirational space and the state's right to do so. As I documented in detail elsewhere, students found often indirect means by which they negotiated individual career aspirations within accepted frameworks to serve the Eritrean cause (author). In fact, a rare student who doubted that one could live in Eritrea as an educated person was Rihab, whose doubts were strongly related to political space. She said then: 'I don't know if our government is going to give us a chance to participate in actual political activities $[\ldots]$ they can't rule the country forever, [...] but I don't know, is it going to happen (interview, Asmara, Eritrea, 26 April 2001).

In parallel, core staff within the university administration began to recognize that in order to maintain this 'personal nationalism' (McCrone, 1998: 40) and commitment of future student cohorts, university practices needed to eventually allow students more input and means to fulfil their personal aspirations (interview, female academic, official role at UoA at the time, Asmara, Eritrea, 27 July 2001).

But before any such measures could be implemented, it was the notion of 'betrayal' that gained the upper hand, followed by a brutal crack-down on any attempt to shift the boundaries of political space. Two moments stand out in relation to higher education that accelerated a process in which the ruling elites proved unable to respond to changed circumstances within Eritrean society and the accompanying altered aspirations of educated youth as a core population group. The first was the academic conference that took place in Asmara in July 2001 in order to mark the tenth anniversary of Eritrean independence. The second, closely intertwined with the first, was the demand for certain work from students during the summer months of 2001 that subsequently became a core milestone in triggering the 
eventual closure of the UoA. Both are being discussed in the following section.

\subsection{The 2001 conference and the summer in the desert}

The 2001 international conference in Asmara promised to be an important step in a move from top-down political leadership towards a more open form of governance where political action could be undertaken jointly by state/party bodies and other societal actors combined. It was held at a time when social and economic progress of the post-independence years had been reversed as a result of renewed war with Ethiopia between 1998-2000, triggered by the inability of the political leadership in both countries to solve conflicting interpretations of boundaries and currency politics in other ways (Giorgis, 2014; Negash and Tronvoll, 2000).

The war's aftermath and the military defeat for Eritrea saw a marked slow-down of developmental achievements and the erosion of political legitimacy resulting in an increasing number of ordinary citizens questioning the EPLF/PFDJ hegemonic project (Bernal, 2004; Müller, 2012a).

The conference, entitled Independent Eritrea: Lessons and Prospects, could have served as a platform to radically transform the political landscape. It was characterized by frank debates and many high profile intellectuals with a critical stance towards state policies from within Eritrea and from outside presented their views.

The conference ended on 26 July 2001 and two days later the yearly graduation ceremony at the UoA took place. At the ceremony student leader Semere Kesete voiced students' concern about the low payment offered for compulsory summer work in which students were asked to carry out statistical surveys in remote rural areas, ${ }^{2}$ and demanded more say by students in areas that directly affected them. 
Journal of Development Studies, accepted manuscript version, 16/03/2017

Instead of engaging with student demands for higher financial compensation at a time when many of their families faced economic hardship as a consequence of the latest war, Semere Kesete was arrested, as were subsequently a number of those students who gathered outside the High Court for his initial hearing. The government through its actions thus interpreted the refusal to accept the economic conditions of additional summer work as a political challenge to its authority by the student population. In turn, it replaced the anticipated survey work with a measure of collective punishment. All UoA students were summoned and then driven first to Wi'a in the Danakil desert, and later transferred to Ghela'elo for auxiliary work activities in a measure that was predominately punitive in nature (Müller, 2008). Almost ironically, the method to use stints of work in the countryside in order to enforce student behaviour was something those who now made that decision had been exposed to themselves. A leading government/PFDJ official remembers how he came to join the EPLF:

I did not finish [my studies in Addis Ababa], you know, in 1974, the Derg came up with this programme where all students were supposed to go to the countryside for literacy campaigns and for helping the peasants, but it was mainly a propaganda campaign for the Derg, and it was also a means of getting rid of the especially highschool and university students from the towns [...] so rather than joining it, I came to join the EPLF ... (my emphasis) (interview, male, former EPLF fighter, now ministry official, Asmara, Eritrea, 23 December 2000).

The harsh government crackdown on the student population is more broadly related to the political crisis that evolved in the aftermath of the war with Ethiopia that saw critical voices raised publicly from within higher echelons of the PFDJ for the first 
time (for those dynamics see Connell, 2005 and Reid, 2009). Many of the issues raised by the so-called G15 in an open letter were debated at the conference discussed above, where a number of critical papers were also presented by staff and students of the UoA, confirming in the eyes of key government officials that university students (and staff) were 'unpatriotic'.

The summer of 2001 thus proved pivotal in the closing down of what political space had previously opened up (for a broader discussion of these dynamcis see Connell, 2011; Tronvoll and Mekonnen, 2014). In relation to higher education, it marked the last incident of visible student contestation of government orders and was the beginning of structural changes within the education system aimed at enforcing loyalty. The latter included the eventual closure of the UoA and the opening of the Eritrean Institute of Technology (EIT) in Mai Nefhi partly under army control. The year 2001 thus initially ushered in a period of accelerated closure of visible political space even if subtle forms of contestation always existed.

Dynamics since have been in flux for a number of years now and in the higher education sector, changes at the colleges that replaced the UoA have opened up room for pursuing personalised aspirations within the system, and in doing so changed the perceived boundaries of political space. In 2006 the biggest of those, the EIT in Mai Nefhi near the capital Asmara, was run more like a military camp than an educational establishment, and harsh disciplinary regimes determined students' lives, not only restricting fundamental freedoms but draining any motivation to study (Reid, 2009). By 2011 this scenario had been transformed not only in relation to how the college was administered but also in terms of student motivations and perceptions. Not dissimilar from students at the former UoA, being admitted to Mai Nefhi was used in various ways to combine professional aspirations with imposed citizenship 
obligations (for details see Müller, 2012b). This process amounts to an attempt to shift the boundaries of political space, and students are acutely aware that to carve out space to fulfil personalised aspirations requires a constant balancing act in relation to state-set obligations. The next section will discuss such balancing acts and how these have been enacted over time with a focus on three individual life histories; these were chosen as they also exemplary illustrate wider repercussions for state policy objectives.

\section{Balancing personal aspirations with citizenship obligations: three stories}

The following focus on the concrete lives of some of those in higher education allows for an in-depth analysis of the relational dynamcis of real and perceived political space. It will show in detail how the aspirations of an educated person interact with or contest a seemingly all-powerful state, and in what way these actions transform the boundaries of aspirational political space, or fail to do so.

As discussed in the previous section, the Eritrean government's post-liberation statebuilding agenda has the propensity to sacrifice personal advancement for the nation at its core. At the same time, in its drive for national development the EPLF/PFDJ subscribes to a progressive, modernist agenda, for which knowledge and skills are essential, and that to be successful needs the active participation of those who posses those skills. What state actors overlook in this equation is that its modernist agenda has laid the very foundations for the contestation of the party's top-down hegemonic vision for the post-liberation state, and the sector of higher education is one where this comes particularly to the fore. Due to the state-enforced limitations of political space outside the PFDJ-defined singular notion what it means to be Eritrean, contestation is most prevalent and often only possible in relation to personalised aspirations. In turn, 
realizing those aspirations becomes an act of political defiance or an expansion of political space. It at the same time challenges the PFDJ-accusation of 'betrayal' against those who interpret enforced citizenship obligations in their own way, as many who do so remain committed to the wider Eritrean state-building project (Müller, 2012a; Reid, 2009).

The following sections will interrogate those dynamics in concrete depth through the presentation of three life-trajectories of former students of the UoA who graduated before its closure in 2006. Their narratives will help to analyse some of the complex and often contradictory dynamics of post-liberation politics in Eritrea. In addition, they throw some concrete light on how state-politics and the internalisation of boundaries of political space are being played out in the individual lives of some of those who have been educated as key professionals for future national development.

\subsection{Failure of balancing aspirations with perceived citizenship obligations:}

\section{Benefitting from the EPLF's social agenda but never a follower}

The first narrative centres on 'Elmi'. 3 She comes from a village outside Keren and belongs to a minority ethnic group. Because her father was literate he was forced by the Ethiopian Derg government to work in the city administration of Keren during the 1980s. This meant the family needed to move to Keren as they now feared reprisals from EPLF fighters who would regard them as traitors. The move to Keren enabled 'Elmi' to attend school and when independence came she had successfully completed primary education within the old Ethiopian system. By that time her two older sisters had been married, both at the age of 14 , and her parents tried to arrange for her to get married as well, as within her family the cultural tradition of early marriage for girls was of great importance. 
'Elmi' was an excellent student and her sole concern was to continue her education, which was eventually made possible by the general value the EPLF/PFDJ government gave to education, combined with the intervention of a sympathetic school director who convinced her parents. When she had reached grade ten, two students from her school had the opportunity to participate in an exchange programme with a school abroad. 'Elmi' was chosen and her parents agreed to let her go. 'This changed my life forever', she says in retrospect, and after her return she was more committed than ever to continue her education to the highest level possible, not in order to play an important part in the reconstruction of Eritrea, but as a life strategy that would allow her to fulfil personal aspirations.

'Elmi' always considered herself as un-political and even though the opportunity to continue her education was in important ways linked to the progressive social agenda of the EPLF/PFDJ not least in relation to girls' education, she never felt particular sympathy for the movement/party. Due to her good academic performance she was admitted to the UoA and graduated with excellent grades. Subsequently 'Elmi' worked for the cultural section of the PFDJ carrying out social science research - in many ways a dream job for any UoA graduate in her field, not least because she was paid a proper salary (not the national service allowance) and had the opportunity to travel within the country. Her superiors liked her work and she was given some freedom in determining what actual projects to pursue. Being a researcher and eventually study for a Masters and /or PhD was her ultimate career ambition and there was every indication that she would be sent for study at Masters level eventually. What she was also aware of, however, was that while 'for now I research what I am interested in, maybe one day they [referring to those in power in general] will simply tell me what to do.' 
'Elmi' never had to do any substantial amount of military service - a six week stint in Ghatelei and the summer work programme in Wi'a/Ghela'elo described above. She conducted work she enjoyed, and could have become one of a group of social history researchers that helped establish a national archival depository. Instead, from a government-financed trip to attend a conference in Europe she did not return. 'Elmi' meanwhile got asylum in a European country, using the general narrative of persecution in Eritrea to support her claim, where she lives with her (Eritrean) husband and four children from state hand-outs and the occasional part-time work. She is frustrated that she will in all likelihood never be able to continue her education, but tries to make the best of her life. Almost ironically, she in fact lives a very 'traditional' life with regard to gender roles and decision-making power in her family, something she had partly escaped while still in Eritrea, mainly due to genderprogressive state policies.

'Elmi' thus on the face of it had every opportunity to put her aspirations of becoming a social scientist into practice, seemingly supported by government policies. But she was equally concerned that if her research interests failed to align with PFDJ research priorities, her ambitions could be crushed at any time. Her perceptions of political space as a closed space granted through compliance with PFDJ dictates and with little room for manoeuvre eventually made her decide to stay abroad.

5.2 Realising aspirations and citizenship obligations: Balancing acts by a child of the revolution

The second narrative is that of 'Mehret', who can be called a 'child of the revolution'. 'Mehret' was one year old when her parents decided to join the EPLF. Her mother took her to the liberated areas, where she grew up first in a children's 
home and later in the Revolution School. She finished schooling after grade seven and was assigned to teach younger children. It was only after liberation that 'Mehret' could continue her secondary education, which she completed successfully, determined to join the university.

After a year of pleading her release from teaching duties with the Ministry of Education, she joined the UoA and graduated as one of the best students in her subject. She had a strong desire to 'complete my Master's, and hopefully also Ph.D. some day, but I want to come back and live and work here in my country, do something useful'. 'Mehret' became a graduate assistant, first at the UoA then after its closure at the college in Mai Nefhi. And even though she earns by Eritrean standards a decent salary as does her husband, both can only just make ends meet. She told me in 2011 'my children have never seen the sea as it is hard to afford to go to Massawa', referring to the generally high cost of living in Asmara compared to Eritrean salaries. 'Mehret' has meanwhile obtained a Masters degree from a respected University abroad, has returned to Eritrea and her teaching post, and hopes to continue with a $\mathrm{PhD}$ eventually. While watching the video of her graduation with her in 2011 she said 'all those with me there are not here now, I am the only one still in the country'. 'Mehret' has no intention herself of leaving, and on a personal level is content with having had the opportunity for acquiring a respected Masters degree, but for society at large her further studies make little sense. She got a slight salary increase but with her family continues to live in two rooms in the same shared compound, 'we are entitled to apply for a proper house but there are none' she says, and is realistic enough to know they will not get a house any time soon. For people in her extended family and wider society, there are clear expectations. 'You go out and study, and this brings a lot of sacrifices as well', she says, in her case not having seen her young children for almost 
two years, 'and once you come back there is no visible difference in your material condition, people do not really understand that, there are a lot of expectations you cannot meet'.

'Mehret' is a prime example of those who accept the boundaries of political space and the trade off between personalised aspiration and contributing to the wider statebuilding process. And while her story shows that she made this work for her personally, for society at large her sacrifices make little sense.

\subsection{Realising aspirations within a closed political space: Successful professional} career destroyed by EPLF/PFDJ economic policy

The last example is 'Esther', who grew up in Asmara and started secondary school when liberation came, where she stood first in her class in each year. ${ }^{6}$ She joined the third round of military service in Sawa after school completion, but because of her excellent matriculation exams was called back after the summer months to start at the UoA from where she graduated with an engineering degree. 'Esther' had worked for the public works in Asmara as national service requirement, where most of the work was monotonous. She recalls, 'even when there was no work at the office, you were not allowed to leave but had to sit there the whole day with nothing to do', which she really disliked, 'but it has passed, it was only for one year'.

After graduation her main objective was to help her parents and siblings economically and eventually do a Masters. She successfully started her own construction company with her husband and they earned well by Eritrean salary standards. But in September 2005 a government proclamation resulted in the closure of all privately owned construction companies on diffuse charges of corruption in the sector that were never substantiated. This was followed by the arrest of many former company directors in 
April 2006. From then on, only government and/or PFDJ owned construction companies were allowed to operate and the PFDJ owned import-export company became the sole source permitted to import building supplies. At a meeting with 'Esther' in October 2006 the family savings were running low but they were happy to only have been prohibited from working - with them at the time was a friend who had also owned a construction company and who had been imprisoned for some months, and while he did not want to speak about it one could see it had broken him in many ways. Subsequently, 'Esther' found employment at the state-owned Housing Bank where she worked until her husband secured a scholarship in Australia. He was allowed to leave and she secured the papers to eventually follow him with their children.

In 2006, when she already anticipated that in the foreseeable future there would be little chance to work in her profession again in Eritrea, 'Esther' said she really wanted to 'contribute to the reconstruction of my country' and 'in case the government changes I can come back to achieve this aim', but the longer the family has lived outside Eritrea the less likely that will become.

'Esther', not unlike 'Mehret', accepted many of the boundaries of aspirational space, not least the obligation to give some service. The closure of political space and the drive to tighter control of society at large in her case translated into the closure of economic space as well - and made it impossible to continue her career, making leaving the country the only viable option.

\section{The closure of political space and its contradictions}

The three stories presented above help to explore some of the dynamics behind the closure of political space as aspirational space, but also inherent contradictions for 
Eritrea as a post-liberation state. The closure of political space and accompanying citizenship obligations are meant to secure important development objectives of the state and engrain an ethos of sacrifice, but in fact often result in the opposite. All three protagonists have qualifications that in different ways are important for wider developmental objectives, and at least 'Mehret' and 'Esther' are/were committed to use their skills explicitly for the benefit of the country. The fact that only 'Mehret' partially does so throws a concrete light on the inability of Eritrea's ruling elite to adapt to dynamics of socio-economic modernization it itself brought about. When the UoA re-opened shortly after liberation with the narrow developmental vision to educate youth to obliterate human resource shortages, it succeeded to produce cohorts of students like 'Esther' who were willing to combine personal career aspirations with benefitting the country. In a survey I carried out in spring 2001 among 176 women and 183 men students at the UoA, only 80 respondents considered a future outside Eritrea, but even those accepted to work for the government for a few years after graduation, thus acknowledging the boundaries of aspirational space and the right of the state to draw those.

The aftermath of the war with Ethiopia and the various contestations of PFDJ hegemony in its wake changed those dynamics, a process that accelerated with the events following the 2001 graduation ceremony outlined above. It not only marked a closure of political space and enforced a worldview that regards the advancement of personal aspirations as an act of political defiance or betrayal. In parallel, the quest for economic and material betterment became equally contentious and was treated as a threat to its political hegemony by the ruling elite, most visible in the construction industry that had become the major employer in the private sector. The three individual histories bring the wider repercussions of this strategy and the 
dynamics they unleashed to the fore in exemplary fashion. 'Esther's' example shows perhaps most clearly the misfit between viable socio-economic institutions and the almost absolute claim to state ownership by the PFDJ elite. Having been educated for and worked in a field in which there is huge unmet demand in Eritrea, including the provision of housing, the PFDJ-interpretation of economic success in the construction-sector as a threat to its political hegemony has made it impossible to use her skills for Eritrea's development. In 'Esther's' case this has ultimately resulted in her leaving, a fact that unites her with many among the recent Eritrean refugees and migrants who possess the qualifications and skills to create a successful economy but see no way to do so that allows to balance their aspirations with state obligations. Indirectly, this exodus is felt in the lives of people like 'Mehret', who under the government's own rules qualifies for subsidized housing - but no housing is available. The construction industry is one of the prime examples in the monopolization of the economy by the PFDJ and various sections of the military. Similar actions happen periodically on smaller scales to manningfold successful businesses. ${ }^{7}$

Even for 'Mehret', who of late achieved a core feature of her personal aspirations, this took many years. When I met her in 2011 she had grown increasingly impatient waiting to do her Masters, in particular as students had by then been sent abroad again for scholarships. Ultimately, she completed her Masters more than ten years after her first degree.

'Elmi' in contrast was not prepared to endure such a potentially long wait. Even though she was assigned to a type of work she did enjoy, she not only rejected the lack of freedom to leave her position of her own accord, but also that she could not go for further study following her own timetable (even though she would not have had the financial resources to go without a scholarship). But 'Elmi' also found to her cost 
that 'getting out' does not necessarily provide the solution she hoped for. In that she joins the large number of Eritreans who have come to see the exit option as the only viable alternative, often only to realize that the grass is not always greener elsewhere (see for example Treiber, 2013). For those in higher education, who are among the most privileged youth in Eritrea, recently adjusted state practices in relation to political space not necessarily provide more scope for balancing citizenship obligations with personal aspirations, as the following will discuss.

\section{Political space as aspirational space: signs of new openings?}

The cohort of 'Mehret' and subsequent post-2001 graduates are not unusual in having a majority of members outside the country, as Eritrea by 2015 had become one of the principal sources of refugees worldwide in relation to its population size (International Crisis Group, 2014). An important group among those who initially fled were university-educated youth accused of 'unpatriotic' behaviour - when all they did was insisting to fulfil citizenship obligations in their field of expertise, an act that was interpreted as a challenge to its control of political space by state bodies (see Müller, 2016).

Over time, it was recognised that Eritrea cannot afford to lose the qualified youth it invested in with free higher education, people like 'Esther', who had no desire to leave but were forced to do so by government policies, at the current rate.

The almost 'psychotic obsession' (interview, foreign ambassador, Asmara, Eritrea, October 2015) to get out even by those whose lives were not directly determined by restrictive government measures, were more and more undermining important development objectives.

In relation to the higher education sector this has led to a number of measures 
allowing for more aspirational space: Since 2015, the most recent graduates are paid salaries according to their qualification and no longer the national service 'wage' - a scheme anticipated to be extended to previous cohorts eventually. ${ }^{8}$ In order to address the shortage of qualified local staff, students are being sent abroad for scholarships to pursue Masters or $\mathrm{PhD}$ degrees again, even if thus far only a minority has returned upon completion. ${ }^{9}$ Those who have done so, including a former Masters student with a degree in the lucrative field of computer science, can rise to important positions within the higher education sector and thus like 'Mehret' more easily alien personal aspiration with citizenship obligations - in his case heading the ICT and Teleeducation Centre at Mai Nefhi (interview, male, lecturer, Asmara, Eritrea, 28 October 2015).

The Tele-education Centre offers an additional way to complete a Masters degree through 'live' tele-study sessions with instructors at a university in India (interview, male, participant in Tele-education Masters programme, Asmara, Eritrea, 24 October 2015). Lastly, Masters programmes have started within Eritrea, and I had the opportunity to visit such a programme in a science subject. ${ }^{10}$ Some of its participants belong to a similar cohort as 'Merhet', meaning they had waited for more than ten years for this opportunity. They bemoaned the lack of laboratory and experimental equipment, as 'Fitsum' says: 'It is not fulfilling to only study everything in theory'. He hopes to eventually complete a PhD abroad, 'my grades are excellent but it depends on the opportunities you can be given in the environment you find yourself in' is how 'Fitsum' describes the situation, acknowledging that in fact aspirational space remains largely closed.

The same sentiment is voiced by a younger generation of students, as this example from the department of Pharmacy illustrates: Talking to three pharmacy students in 
year four in the cafeteria they describe how the general state of affairs in their subject has impacted their studies as well as their outlook for the future. ${ }^{11}$ On the one hand they feel privileged being able to attend college, but 'we are also aware we cannot do much with our degree, nobody recognises it'. Their main concern are not the shortages in laboratory facilities, or of water and electricity, but the quality of their degree. This unites them with students like 'Fitsum', as what students ultimately strive for is to complete their degrees at a (internationally) recognised academic institution. Since the closure of the UoA that came about as a means to tightly control political space 'there is no higher education in this country' (interview, male, former lecturer, Asmara, Eritrea, 21 October 2015), which in the minds of students' implies that their degree is ultimately of little value.

This points to the fact the UoA as a 'proper' university was not only regarded as a key educational institution, but symbolised hope and future aspirations for bright and ambitious youth - while symbolizing a threat to the state that needed reigning in. Its replacement (instead of supplementation) with decentralized, technocratic-centred colleges was thus an important symbolic act in crushing aspirational space.

The three pharmacy students are well aware of the possibilities the outside world may offer, and have multiple family connections to the diaspora. Essentially, each of them could become another version of either 'Mehret' or 'Esther'. If they are given the opportunity for a viable professional career in Eritrea, they might indeed stay. But if the opportunity to pursue such a career is severely constrained by increased service requirements as citizenship obligations or other obstacles as was the case for 'Esther', they are undoubtedly going to join their diaspora-networks.

Many of those who have actively decided to stay and still have ambitions for the future would most likely agree with 'Fitsum' when he says about his prospects to 
eventually do a $\mathrm{PhD}$ 'the probability is zero, but the hope is 100 '. It should be noted here that a small cohort exists who are successful in combining personal advancement with state obligations. They either work in areas of symbolic importance that are not subject to much interference by organs of the state such as archaeology or the preservation of architecture, ${ }^{12}$ or have become PFDJ members and advance their careers through party politics (interview, male, lecturer, Asmara, Eritrea, 28 October 2015).

For others reluctant to leave, a new way of incorporating hope into everyday life practices and through this extend the boundaries of political space has emerged through the Orthodox church. Traditionally shunned by young people, in the wake of the closure of Pentecostal churches and other religious groupings the Orthodox church introduced new features into its services in order to attract youth. At the outbreak of dusk in Asmara, one can thus observe masses of youth streaming to a building behind the main Orthodox cathedral, Nda Mariam, for a prayer service as if being pulled by a gravitational force. This turn towards Orthodox religion can also be observed among those in higher education. The Orthodox church in the vicinity of Mai Nefhi College for example is heavily frequented by students, and for special religious festivals many students walk to a monastery some distance away to take part in the festivities. Thus far, the government does not interfere but mainly observes these dynamics with curiosity. A government official confides 'for us, this is difficult to understand, when we were young we wanted to make a revolution and moved away from religion' (interview, male, former EPLF fighter, now Ministry official, Asmara, Eritrea, 27

October 2015). This turn to religion can be interpreted as another form of escape from some of the realities of daily life and the way this is determined by strict government dictates. The 'turn' presents a subtle way of widening political space as a spiritual 
space beyond government reach. It includes people like 'Mehret', who not least through her upbringing in the revolution school was not socialised with religion and through most of her adult life did not engage with religious activities, but for whom the Orthodox faith now offers a way of making sense of the various paradoxes in her life discussed above (fieldwork diary, 24 October 2015).

The latest official act with the potential to transform political space in a more profound way came in form of the first International Conference on Eritrean Studies since 2001, held in Asmara in July 2016. But whereas the 2001 conference was characterised by critical debate on the political situation in Eritrea, the framing of the 2016 conference was narrowly defined: The ‘truth' about Eritrea was to be discussed in order to counter negative narratives by those scholars who did not pay enough attention to the particular conditions of Eritrea. The conference thus gave Eritrean researchers in particular a platform to present their work - as long as it dealt with development centred topics that outlined achievements and future challenges, and its participants internalised the boundaries of this framing. The 2016 conference might thus have represented a small step towards more openness; but it failed to enable a widening of the boundaries of political space, or profoundly challenge the top-down dynamics of state-citizen relations.

\section{Conclusion}

This article has provided a reading of Eritrea's post-liberation trajectory through an empirical focus on life histories of educated youth and dynamics within the higher education sector. It has used the concept of political space, defined as an aspirational space whose boundaries are being created in constant balancing acts between personal aspirations and enforced citizenship obligations, to interrogate the nature of the 
contemporary Eritrean state. This focus has allowed an analysis of how the everydayexperience of a (perceived) all-powerful post-liberation state gets internalized and interacts with aspirations of educated youth who are groomed to be key contributors to state development objectives.

The article has analysed how a partly progressive political agenda that offered youth new educational opportunities and widened the scope for future aspirations has subsequently curtailed those aspirations through tight control mechanisms and the closure of political space. Even among those in higher education willing to contribute to national development objectives as defined by the ruling elite, the tensions between state obligations and personal aspirations have resulted in contradictory dynamics that ultimately undermine important state objectives, including the high propensity of (educated) youth to leave the country. The government has started to address some of the shortcomings in relation to higher education as it sees them, including higher pay and renewed opportunity for future study. In this it fails to understand that the root cause of dissatisfaction among youth in higher education is psychological in nature and related to notions of what a proper life for young educated youth should entail. Since the closure of political space in 2001 , and even with more recent scope to extend its boundaries through for example overseas study or religion, little has changed in the experience of the state as all-powerful and ultimately able to crush the aspirational space that has opened up for some. In turn, only a small minority of educated youth manage the constant balancing act between personal aspirations and enforced citizenship obligations successfully, making the tight boundaries of political space dysfunctional when looking at the longer term prospect of Eritrea's postliberation politics. 
These dynamics link Eritrea to other post liberation regimes in Africa and beyond in relation to mobilising youth to become important future contributors to post-liberation projects but at the same time permitting little independent agency or aspirations.

Acknowledgements: Firstly I wish to thank all Eritreans who have shared their stories and experiences with me over many years. An initial version of this paper was presented at an event in Oxford entitled 'Eritrea and Rwanda: Post-liberation trajectories in comparative perspective' in December 2014, and I thank all participants for constructive comments and engagement, in particular the organiser Jason Mosley. I also thanks the reviewers for useful suggestions to improve the paper.

Biographical Details: Tanja R. Müller is Senior Lecturer in International Development at the Global Development Institute and the Humanitarian \& Conflict Response Institute, both at the University of Manchester. She has written on the Horn of Africa in general and Eritrea in particular since the 1990s. Her latest book is Legacies of Socialist Solidarity (2014).

\section{ENDNOTES}

${ }^{1}$ For full details of methodology and data analysis procedures see author.

${ }^{2}$ The lump-sum payment of 800 Nakfa on offer would have translated into 26 Nakfa per day whereas the official rate for such kind of work was $50 \mathrm{Nakfa}$ per day at the time.

${ }^{3}$ All names have been changed for reasons of confidentiality and other markers that could easily identify informants have been removed. The following is based on various personal encounters with 'Elmi' during the academic year 2000/2001 and each year after until 2006 in Eritrea. I subsequently met 'Elmi' in a European city in 2011. 
${ }^{4}$ The following is based on various personal encounters with 'Mehret' during the academic year 2000/2001 and each year after until 2006, and again in 2011, 2015 and 2016 in Eritrea, plus various exchanges via Facebook.

${ }^{5}$ All those from the batch of students who took part in my original research that I am aware of are indeed abroad, mostly in the US, and went there by legal means after having completed national service and received release papers. This is not unusual for this cohort but has become almost impossible in subsequent years and the vast majority who have fled since then did so by illegal means.

${ }^{6}$ The following is based on various personal encounters with 'Esther' during the academic year 2000/2001 and each year after until 2006, and via email and Facebook since.

${ }^{7}$ There is a pattern in periodic government crackdowns when any business sector or individual business becomes too economically successful. These either face difficulties in gaining import licences and/or are forced to close temporarily (interview, male, business owner, Asmara, Eritrea, 28 October 2015; interview, male, manager, Asmara, 23 October 2015).

${ }^{8}$ For those working outside the higher education sector this payment amounts to 1650-1800 Nakfa per months, for those inside to 3800 Nakfa. The official exchange rate at the time of writing is $1 \mathrm{US} \$=10 \mathrm{Nakfa}$.

${ }^{9}$ Eritrean students are currently studying in a number of foreign countries, including China, Thailand, South Korea, Turkey, Russia, Kenya and Sudan.

${ }^{10}$ The following is based on conversations and observations in Asmara in October 2015. Names have been changed.

${ }^{11}$ The three students, two women and one man, were in their early twenties. The conversation took place on 22 October 2015. Names have been changed. 
Journal of Development Studies, accepted manuscript version, 16/03/2017

${ }^{12}$ A number of archaeology graduates work for the National Museum in Asmara that has a number of collaboration programmes with Italy. A team of committed Youth work at the Asmara Heritage Project that prepares a bid to have Asmara's modernist architecture recognised as a UNESCO World Heritage Site by 2017 (Boness, 2016). 
Journal of Development Studies, accepted manuscript version, 16/03/2017

\section{REFERENCES:}

Ammar, W.-Y. (1997). The role of Asmara students in the Eritrean nationalist movement: 1958-68. Eritrean Studies Review, 2, 59-84.

Appadurai, A. (2004). The Capacity to Aspire: Culture and the Terms of Recognition. In V. Rao and M. Walton (Eds), Culture and Public Action (pp. 59-84). Stanford, CA: Stanford University Press.

Bariagaber, A. (2013). Globalization, imitation behaviour, and refugees from Eritrea. Africa Today, 60, 2-18.

Bayly, S. (2004). Vietnamese Intellectuals in revolutionary and postcolonial times. Critique of Anthropology, 24, 320-344.

Bernal, V. (2013a). Civil society and cyberspace. Reflections on Dehai, Asmarino, and Awate. Africa Today, 60, 20-36.

Bernal, V. (2013b). Please forget democracy and justice. Eritrean politics and the powers of humour. American Ethnologist, 40, 300-309. DOI:

10.1111/amet.12022

Bernal, V. (2006). Diaspora, cyberspace and political imagination: the Eritrean diaspora online. Global Networks, 6, 161-179.

Bernal, V. (2004). Eritrea goes global: Reflections on nationalism in a transnational era. Cultural Anthropology, 19, 3-25.

Beswick, D (2010). Managing dissent in a post-genocide environment: the challenge of political space in Rwanda. Development and Change, 41, 225-251.

Boness, S. (2016). Asmara: Africa's Jewel of Modernity. Berlin: Jovis.

Boudreau, J.-A. (2007). Making new political spaces: mobilizing spatial imaginaries, instrumentalizing spatial practices, and strategically using spatial tools. Environment and Planning A, 39, 2593-2611. 
Journal of Development Studies, accepted manuscript version, 16/03/2017

Bozzini, D. (2015). The fines and the spies. Fears of state surveillance in Eritrea and in the diaspora. Social Analysis, 59, 32-49. doi:10.3167/sa.2015.590403

Bratton, M. (1989). Beyond the State: Civil Society and Associational Life in Africa. World Politics, 41, 407-430.

Burgess, T. (2005). The young pioneers and the rituals of citizenship in revolutionary Zanzibar. Africa Today, 51, 3-29.

Carothers, T. (2002). The end of the transition paradigm. Journal of Democracy, 13, $5-21$.

Connell, D. (2011). From resistance to governance. Eritrea's trouble with transition. Review of African Political Economy, 38, 419-433.

Connell, D. (2005). Conversations with Eritrean political prisoners. Trenton, NJ: Red Sea Press.

Dorman, S. (2006). Post-liberation politics in Africa: examining the political legacy of struggle. Third World Quarterly, 27, 1085-1101.

Fukuyama, F. (1992). The end of history and the last man. New York: The Free Press.

Giorgis, A. W. (2014). Eritrea at a crossroads. A narrative of triumph, betrayal and hope. Strategic Book Group.

Harvey, D. (2006). Space as a key word. In N. Castree and D. Gregory (Eds), David Harvey: A Critical Reader (pp. 270-293). Oxford: Blackwell.

Hepner, T. (2003). Religion, Nationalism, and Transnational Civil Society in the Eritrean Diaspora. Identities. Global Studies in Culture and Power, 10, 269293. DOI: $10.1080 / 10702890390228874$

Hepner, T.; Tecle, S. (2013). New Refugees, Development-Forced Displacement, and Transnational Governance in Eritrea and Exile. Urban Anthropology, 42, 377410. 
Journal of Development Studies, accepted manuscript version, 16/03/2017

Hirt, N. (2015). The Eritrean Diaspora and its impact on regime stability: Responses to UN sanctions. African Affairs, 114, 115-135. doi: 10.1093/afraf/adu061

Hirt, N. (2000). Eritrea zwischen Krieg und Frieden. Die Entwicklung seit der Unabhängigkeit. Hamburg: Institut für Afrikakunde.

Hirt, N.; Abdulkader, S. M. (2013). "Dreams don't come true in Eritrea": Anomie and Family Disintegration due to the Structural Militarisation of Eritrean Society. Journal of Modern African Studies, 51, 139-168.

Humphris, R. (2013). Refugees and the Rashaida: human smuggling and trafficking from Eritrea to Sudan and Egypt. Policy Development and Evaluation Series, research paper no. 254, UNHCR, Geneva.

Huntington, S. (1991). The third wave. Democratisation in the late twentieth century. Oklahoma City: University of Oklahoma Press.

International Crisis Group. (2014). Eritrea: Ending the Exodus? Africa Briefing no. 100, ICG, Nairobi/Brussels.

Kibreab, G. (2009). Forced Labour in Eritrea. Journal of Modern African Studies, 47, 41-72. doi:10.1017/S0022278X08003650

Kriger, N. (2006). From patriotic memories to "patriotic history" in Zimbabwe, 19902005. Third World Quarterly, 27, 1151-1169.

McCrone, D. (1998). The sociology of nationalism. London: Routledge.

Müller, T.R. (2014). Legacies of Socialist Solidarity. East Germany in Mozambique. Lanham: Lexington Books.

Müller, T.R. (2012a). From rebel governance to state consolidation - Dynamics of loyalty and the securitization of the state in Eritrea. Geoforum, 43, 793-803. Müller, T.R. (2012b). Beyond the siege state - tracing hybridity during a recent visit to Eritrea. Review of African Political Economy, 39, 451-464. 
Journal of Development Studies, accepted manuscript version, 16/03/2017

Müller, T.R. (2008). Bare life and the developmental state: implications of the militarisation of higher education in Eritrea. Journal of Modern African Studies, 46, 111-131.

Müller, T.R. (2007). Education and gender in revolutionary societies: insights from Vietnam, Nicaragua, and Eritrea. Compare, 37, 635-650.

Müller, T.R. (2004). 'Now I am free' - Education and Human Resource Development in Eritrea: Contradictions in the Lives of Eritrean Women in Higher Education. Compare, 34, 215-229.

Negash, T.; Tronvoll, K. (2000). Brothers at war. Making sense of the EritreanEthiopian war. Oxford: James Currey.

Opas, M., McMurray, D. 2015. Under the Gaze of the State: ICT Use and State Surveillance of Eritrean Refugees in Italy. Refugee Survey Quarterly, 34, 105125. doi: $10.1093 / \mathrm{rsq} / \mathrm{hdv} 013$

Ottaway, M. (1999). Africa's new leaders. Democracy or state reconstruction? Washington DC: Carnegie Endowment for International Peace.

Panzer, M. (2009). The Pedagogy of Revolution: Youth, Generational Conflict, and Education in the Development of Mozambican Nationalism and the State 1962-1970. Journal of Southern African Studies, 35, 803-820.

Pool, D. (2001). From guerrillas to government. The Eritrean People's Liberation Front. Oxford: James Currey.

Poole, A. (2013). Ransoms, remittances, and refugees: the gatekeeper state in Eritrea. Africa Today, 60, 66-82.

Reid, R. (2014). Writing Eritrea: history and representation in a bad neighbourhood. History in Africa, 41, 83-115. 
Reid, R. (2009). The politics of silence: Interpreting stasis in contemporary Eritrea. Review of African Political Economy, 36, 209-221.

Reid, R. (2005). Caught in the headlights of history: Eritrea, the EPLF and the postwar nation-state. Journal of Modern African Studies, 43, 467-488.

Riggan, J. (2016). The Struggling State. Nationalism, Mass Militarization, and the Education of Eritrea. Philadelphia: Temple University Press.

Riggan, J. (2013). Imagining Emigration: Debating National Duty in Eritrean Classrooms. Africa Today, 60, 84-106.

Sabar, G., Rotbard, A. (2015). Eritrean Asylum Seekers' Lament Ceremonies in Israel as Contested Sites of Identity Formation. African Diaspora, 8, 147-173.

Tecle, S., Goldring, L. (2013). From 'remittance' to 'tax': the shifting meanings and strategies of capture of the Eritrean transnational party-state. African and Black Diaspora: An International Journal, 6, 189-207.

Treiber, M. (2013). Lessons for life. Two migratory portraits from Eritrea. In A. Triulzi and R. McKenzie (Eds), Long journeys. African migrants on the road, (pp. 187-212). Leiden: Brill.

Treiber, M. (2009). Trapped in Adolescence: The Postwar Urban Generation. In D. O'Kane and T. Hepner (Eds), Biopolitics, Militarism, Development: Eritrea in the 21st Century, (pp. 92-114). Oxford: Berghahn Books.

Tronvoll, K., Mekonnen, D. (2014). The African garrison state. Human rights \& political development in Eritrea. Woodbridge: James Currey.

Valentin, K. (2007). Mass mobilisation and the struggle over youth. The role of Ho Chi Minh Communist Youth in urban Vietnam. Young, 15, 299-315.

Van de Walle, N. (2002). Elections without Democracy: Africa's Range of Regimes. Journal of Democracy, 13, 66-80. 
Journal of Development Studies, accepted manuscript version, 16/03/2017

Woldemikael, T. (2013). Introduction: Postliberation Eritrea. Africa Today 60, v-xix.

$\mathrm{Xu}, \mathrm{L}$. (2010). From revolutionary rebels to a thinking generation: a reflection on

China's Red Guard movement of the mid-1960s. The sixties: A Journal of History, Politics and Culture, 3, 143-160. 
Journal of Development Studies, accepted manuscript version, 16/03/2017 